\title{
EFEKTIFITAS PELAKSANAAN EKSEKUSI HUKUMAN CAMBUK TERHADAP PELAKU JINAYAT DI KABUPATEN ACEH TAMIANG DALAM PERSPEKTIF QANUN HUKUM ACARA JINAYAH
}

\author{
Taryadi \\ Dosen Prodi Hukum Universitas Sains Cut Nyak Dhien Langsa \\ Jln. Ahmad Yani No. 218 Kota Langsa - Aceh \\ tar_yadi27@yahoo.com
}

\begin{abstract}
Qanun Number 7 of 2013 concerning J inayat Procedural Law, Article 247 paragraph 2 explains the implementation of the whip uqubat in paragraph (1) immediately implemented after the Court's decision, but the caning sentence is not carried out by the government. Aceh Qanun Number 7 of 2013, The effectiveness of whip execution for jinayat violations in Aceh Tamiang District in the perspective of the J inayah Procedural Qanun as well as challenges in implementing whip execution against the use of jinayat in Aceh Tamiang District. This research uses descriptive method using normative juridical, as well as field research. Aceh Qanun Number 7 of 2013 is regulated in Articles 247, 252 and 252 namely the public prosecutor who has permission to carry out caning in coordination with the Wilayatul Hisbah Service in the execution of the execution. The effectiveness of the execution of caning of jinayat was not yet optimal after the passing of the Syar'iyah Court ruling. Obstacles to the execution of caning are that the legal apparatus is not compliant with the law, there is no support from the local government both funds and other resources for the execution of caning. While the effort that can be done is the need for an appropriate budget for the implementation of caning and professionalism of law enforcement.
\end{abstract}

Keywords: Implementation, Whip, J inayah

\begin{abstract}
Abstrak
Qanun Nomor 7 Tahun 2013 tentang Hukum Acara Jinayat, Pasal 247 ayat 2 menjelaskan pelaksanaan uqubat cambuk pada ayat (1) segera dilaksanakan setelah adanya putusan Mahkamah, namun hukuman cambuk tidak dilaksanakan oleh pemerintah. Tujuan penelitian untuk mengetahui pengaturan pelaksanaan eksekusi hukuman cambuk berdasarkan Qanun Aceh Nomor 7 tahun 2013, Efektifitas pelaksanaan eksekusi hukuman cambuk terhadap pelaku jinayat di Kabupaten Aceh Tamiang dalam perspektif Qanun Hukum Acara Jinayah serta hambatan dan upaya dalam pelaksanaan eksekusi hukuman cambuk terhadap pelaku jinayat di Kabupaten Aceh Tamiang. Penelitian ini menggunakan metode deskriptif dengan pendekatan Juridis normatif, serta penelitian lapangan. Hasil penelitian bahwa pengaturan pelaksanaan eksekusi hukuman cambuk berdasarkan Qanun Aceh Nomor 7 tahun 2013 diatur dalam Pasal 247, 252 dan 252 yaitu jaksa penuntut umum memiliki kewenangan untuk melaksanakan pencambukan dengan berkoordinasi dengan Dinas Wilayatul Hisbah dalam pelaksanaan eksekusi. Efektifitas pelaksanaan eksekusi hukuman cambuk terhadap pelaku jinayat belum berjalan secara optimal setelah inkrahnya putusan Mahkamah Syar'iyah. Hambatan pelaksanaan eksekusi hukuman cambuk yaitu aparatur hukum tidak patuh
\end{abstract}


hukum, tidak ada dukungan dari pemerintah setempat baik alokasi dana maupun sumber daya lainnya untuk pelaksanaan hukuman cambuk. Sedangkan upaya yang dapat dilakukan adalah perlunya anggaran yang memadai bagi pelaksanaan cambuk dan Profesionalitas penegak hukum.

Kata Kunci : Pelaksanaan, Cambuk, Jinayah

\section{Pendahuluan}

Undang-Undang Dasar negara Republik Indonesia Tahun 1945 yaitu Negara Republik Indonesia mengakui dan menghormati kepada satuan-satuan pemerintah daerah yang bersifat khusus atau istimewa yang diatur dalam Undang-Undang. Pasal 18B Undang-Undang Dasar negara Republik Indonesia 1945 melahirkan Undang-Undang Nomor 44 tahun 1999 Tentang Penyelenggaraan Keistimewaan Provinsi Daerah Istimewa Aceh. Keistimewaan yang diberikan untuk Provinsi Aceh merupakan penghargaan yang diberikan oleh pemerintah kepada masyarakat Aceh atas kesetiaannya yang rela menyerahkan harta dan nyawa untuk tegaknya Negara Kesatuan Republik Indonesia.

Aceh merupakan salah satu daerah provinsi yang diberikan kekhususan oleh pemerintah pusat berdasarkan Undang-undang Nomor 11 tahun 2006 tentang pemerintahan Aceh. Salah satu bentuk kekhususan tersebut dapat dilihat dengan adanya pelaksanaan Syari'at Islam yang dimana setiap masyarakat wajib mentaati segala peraturan yang bersendikan nilai-nilai islam.

Salah satu peraturan yang diatur di Provinsi Aceh adalah mengenai tindak pidana Islam atau yang lebih kenal disebut dengan Qanun Jinayah atau Qanun Provinsi Aceh Nomor 6 Tahun 2004 tentang Hukum Jinayat. Dalam sistem Hukum Pidana Islam (jinayat) terdapat beberapa jenis sanksi pidana yang antara lain: Qishosh, Hadd, dan Ta"zir dalam bentuk hukuman cambuk dan denda yang antara lain dapat kita temukan dalam ketentuan pelanggaran khalwat (mesum), maisir (judi), dan khamar (minuman keras).

Pada dasarnya masyarakat Aceh setuju dengan penerapan hukuman cambuk ini bertujuan untuk memberi pelajaran dan efek jera kepada pelanggar syari' at Islam, dan memberi rasa takut kepada orang lain agar tidak melakukan tindak pidana yang sama. Sehingga hukuman cambuk yang telah di jatuhkan dapat memerangi faktor psikologis yang mendorong keinginan untuk melakukan kesenangan yang bertentangan dengan syari'at Islam. Dengan ada nya hukuman cambuk tersebut, pelaku di harapkan dapat melupakan perbuatannya. ${ }^{1}$

Hal ini tentunya sama dengan pendapat Soerjono Soekanto, bahwa hukum itu harus mempelajari hubungan timbal balik antara hukum dengan dengan gejala-gejala sosial lainnya. Maksudnya Sejauhmana hukum itu mempengaruhi tingkah laku sosial dan pengaruh tingkah laku sosial terhadap pembentukkan hukum. ${ }^{2}$

Hukuman cambuk merupakan sejenis hukuman badan yang dikenakan atas terhukum dengan cara mencambuk badannya. Pelaksanaan cambuk adalah kewenangan dan tanggung jawab jaksa. Pencambukan dilakukan setelah putusan hakim mempunyai kekuatan hukum tetap

${ }^{1}$ Eldin H. Zainal, Perbandingan Mazhab Tentang Hukum Pidana Islam, AlMuqarranah Al-Mazahib Fi Al-Jinayah Medan: Fakultas Syari'ah IAIN-SU, 2010, hlm. 54

${ }^{2}$ Sudirman Tebba, Sosiologi Hukum Islam, Yogyakarta;UII Press, 2003, hlm. 1 
yang berpedoman pada ketentuan yang diatur dalam Qanun Nomor 7 tahun 2013 tentang hukum acara jinayah/ hukum formil.

Terdapat beberapa perbedaan antara hukum acara jinayah/formil dengan hukum acara pidana pada umumnya yang dimana diantaranya adalah :

1. Mahkamah berwenang memeriksa, mengadili dan memutuskan suatu perkara jinayat atas dasar permohonan si pelaku jarimah ;

2. Penahanan yang dilakukan untuk kepentingan penyidikan, penuntutan dan pemeriksaan Mahkamah, hanya dapat dilakukan dalam hal adanya keadaan yang nyata-nyata menimbulkan kekhawatiran bahwa tersangka/terdakwa akan melarikan diri, merusak atau menghilangkan barang bukti dan/atau mengulangi jarimah ;

3. Penggunaan kata atau lafazh sumpah diawali dengan "Basmallah" dan "Wallahi”;

4. Penyidik dapat menerima penyerahan perkara dari petugas Wilayatul Hisbah;

5. Adanya perbedaan alat bukti untuk beberapa jenis jarimah; dan

6. Memperkenalkan penjatuhan 'uqubat secara alternatif antara penjara, cambuk, dan denda dengan perbandingan 1 (satu) bulan penjara disetarakan dengan 1 (satu) kali cambuk atau denda 10 (sepuluh) gram emas murni. ${ }^{3}$

Pada huruf (f) disebutkan bahwa 1 kali cambukkan disamakan/ digantikan dengan 1 bulan penjara atau denda 10 gram emas. Bermakna bahwa terdapat multi sistem dalam pelaksanaan penjatuhan hukum terhadap pelaku jinayah.

Kemudian dalam Qanun jinayah menyebutkan juga hal sama yang disebutkan bahwa:

1) Ketentuan "Uqubat Ta'zir" yang ada dalam qanun lain, sebelum qanun ini ditetapkan, disesuaikan dengan 'Uqubat dalam Qanun ini;

2) Penyesuaian sebagaimana dimaksud pada ayat (1) dengan perhitungan, cambuk 1 (satu) kali disamakan dengan penjara 1 (satu) bulan, atau denda 10 (sepuluh) gram emas murni;

3) Dalam hal 'Uqubat dalam qanun lain sebagaimana dimaksud pada ayat (1) bersifat alternatif antara penjara, denda atau cambuk, yang dijadikan pegangan adalah "Uqubat cambuk";

4) Dalam hal "Uqubat" dalam Qanun lain sebagaimana dimaksud pada ayat (1) bersifat alternatif antara penjara atau denda, yang dijadikan pegangan adalah penjara. ${ }^{4}$

Mengenai jenis 'uqubat, di dalam Al-Qur'an sudah disebutkan beberapa jenis seperti; 'uqubat mati (qishash), 'uqubat amputasi (potong tangan), 'uqubat penjara (kurungan dalam rumah, diasingkan), 'uqubat cambuk dan 'uqubat diyat (semacam ganti rugi yang dibayarkan pelaku kepada korban penganiayaan atau keluarga korban pembunuhan) dan 'uqubat denda.

Hal tersebut diatas menimbulkan adanya kesewenang-wenangan dari pemerintah terhadap pelaku jinayat dan berpotensi adanya pelanggaran ham. Karena di dalam qanun tersebut tidak

\footnotetext{
${ }^{3}$ Qanun Aceh Nomor 7 tahun 2013 tentang Hukum Acara Jinayah, Penjelasan Umum

${ }^{4}$ Qanun Aceh Nomor 6 Tahun 2014 tentang Hukum Jinayah, Pasal 73
} 
menyebutkan adanya penerapan hukuman secara sekaligus terhadap pelaku antara cambuk dengan penjara.

Sedangkan Islam sangat mementingkan kemaslahatan ummat nya sehingga hukuman haad diterapkan demi menjamin kelangsungan hidup dan terjaminnya kebutuhan primer

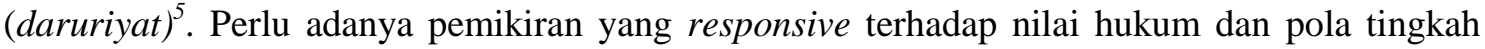
laku masyarakat. Agar hukum tidak dipandang kaku akan tetapi lentur sesuai dengan nilai fakta dan realitas sosial masyarakat. Artinya qanun itu tidak hanya manifestasi dari aturan dasar syari'at yang mesti kita laksanakan akan tetapi juga harus merupakan manifestasi dari masyarakat Aceh.

Jika hanya memandang qanun sebagai aturan syari'at yang mesti kita laksanakan dengan mengabaikan fakta dan realitas yang ada di masyarakat maka dapat dipastikan qanun itu akan berjalan ke arah yang berbeda dengan masyarakat. Akibatnya, Tidak adanya kesesuaian antara hukum atau qanun dengan masyarakat. Menyebabkan tidak berjalannya aturan qanun seperti yang diharapkan dan dicita-citakan.

Hukum itu harus dipandang sebagai suatu lembaga kemasyarakatan yang berfungsi untuk memenuhi kebutuhan-kebutuhan sosial. Dan hukum merupakan suatu aturan yang hidup di dalam masyarakat (living law). Maka hukum (dalam hal ini qanun) yang baik dalam proses pembuatannya harus melihat dari bawah atau dari pandangan masyarakat. Karena awal terealisasinya syari'at Islam itu berdasarkan keinginan dari masyarakat dan ini merupakan fenomena sosial, maka tidak relevan jika dalam pembuatan aturan syari' at (qanun) mengabaikan pandangan masyarakat. Demikian juga dengan aturan qanun yang menerapkan hukuman cambuk bagi masyarakat, tidak hanya sebatas pelaksanaan dari aturan qanun itu, akan terlihat tidak efektif atau bahkan terkesan qanun itu berjalan di tempat.

Sehingga dengan terbentuknya Qanun tersebut realita yang terjadi adalah terhadap pelaku jinayat yang telah memiliki putusan yang berkekuatan hukum tetap yang dijatuhkan oleh mahkamah syar'iyah harus terlebih dahulu di penjara sebelum jatuh pada pelaksanaan hukuman cambuk.

\section{Tinjauan Pustaka}

\section{a. Teori Efektivitas}

Menurut Kamus Besar Bahasa Indonesia, efektif adalah sesuatu yang ada efeknya (akibatnya, pengaruhnya, kesannya) sejak dimulai berlakunya suatu Undang-Undang atau peraturan. ${ }^{6}$ Pada dasarnya efektivitas merupakan tingkat keberhasilan dalam pencapaian tujuan. Efektivitas adalah pengukuran dalam arti tercapainya sasaran atau tujuan yang telah ditentukan sebelumnya.

Ketika kita ingin mengetahui sejauh mana efektivitas dari hukum, maka kita pertama-tama harus dapat mengukur sejauh mana hukum itu ditaati oleh sebagian besar

\footnotetext{
${ }^{5}$ Teungku Ahmad Zamzami, Dkk, Pemikiran ulama dayah Aceh, Jakarta: Prenada, 2007, hlm. 185

${ }^{6}$ Anonimous, Kamus Besar Bahasa Indonesia. Jakarta:Balai Pustaka. 2008, hlm. 284.
} 
target yang menjadi sasaran ketaatannya, kita akan mengatakan bahwa aturan hukum yang bersangkutan adalah efektif. Namun demikian, sekalipun dikatakan aturan yang ditaati itu efektif, tetapi kita tetap masih dapat mempertanyakan lebih jauh derajat efektivitasnya karena seseorang menaati atau tidak suatu aturan hukum tergantung pada kepentingannya. ${ }^{7}$

Achmad Ali berpendapat bahwa pada umumnya faktor yang banyak mempengaruhi efektivitas suatu perundang-undangan adalah profesional dan optimal pelaksanaaan peran, wewenang dan fungsi dari para penegak hukum, baik di dalam penjelasan tugas yang dibebankan terhadap diri mereka maupun dalam penegakan perundang-undangan tersebut. ${ }^{8}$

Sedangkan Soerjono Soekanto menggunakan tolak ukur efektivitas dalam penegakan hukum pada lima hal yakni : ${ }^{9}$

\section{Faktor Hukum}

Hukum berfungsi untuk keadilan, kepastian dan kemanfaatan. Dalam praktik penyelenggaraan hukum di lapangan ada kalanya terjadi pertentangan antara kepastian hukum dan keadilan. Kepastian Hukum sifatnya konkret berwujud nyata, sedangkan keadilan bersifat abstrak sehingga ketika seseorang hakim memutuskan suatu perkara secara penerapan undang-undang saja maka ada kalanya nilai keadilan itu tidak tercapai. Maka ketika melihat suatu permasalahan mengenai hukum setidaknya keadilan menjadi prioritas utama. Karena hukum tidaklah semata-mata dilihat dari sudut hukum tertulis saja. ${ }^{10}$

\section{Faktor Penegakan Hukum}

Dalam berfungsinya hukum, mentalitas atau kepribadian petugas penegak hukum memainkan peranan penting, kalau peraturan sudah baik, tetapi kualitas petugas kurang baik, ada masalah. Selama ini ada kecenderungan yang kuat di kalangan masyarakat untuk mengartikan hukum sebagai petugas atau penegak hukum, artinya hukum diidentikkan dengan tingkah laku nyata petugas atau penegak hukum. Sayangnya dalam melaksanakan wewenangnya sering timbul persoalan karena sikap atau perlakuan yang dipandang melampaui wewenang atau perbuatan lainnya yang dianggap melunturkan citra dan wibawa penegak hukum. Hal ini disebabkan oleh kualitas yang rendah dari aparat penegak hukum tersebut. ${ }^{11}$

\section{Faktor Sarana atau Fasilitas Pendukung}

Faktor sarana atau fasilitas pendukung mencakup perangkat lunak dan perangkat keras, Menurut Soerjono Soekanto bahwa para penegak hukum tidak dapat bekerja dengan baik, apabila tidak dilengkapi dengan kendaraan dan alat-alat komunikasi yang proporsional. Oleh karena itu, sarana atau fasilitas mempunyai peranan yang sangat penting

\footnotetext{
${ }^{7}$ Achmad Ali. Menguak Teori Hukum (Legal Theory) dan Teori Peradilan (Judicialprudence)Termasuk Interpretasi Undang-Undang (Legisprudence). Jakarta: Kencana, 2009, hlm. 375.

${ }^{8}$ Ibid. hlm. 379

${ }^{9}$ Soerjono Soekanto, Faktor-Faktor yang Mempengaruhi Penegakan Hukum, Jakarta: PT. Raja Grafindo Persada. 2007, hlm. 5

${ }^{10}$ Ibid. hlm. 8

${ }^{11}$ Ibid. hlm. 21
} 
di dalam penegakan hukum. Tanpa adanya sarana atau fasilitas tersebut, tidak akan mungkin penegak hukum menyerasikan peranan yang seharusnya dengan peranan yang aktual. $^{12}$

\section{Faktor Masyarakat}

Penegak hukum berasal dari masyarakat dan bertujuan untuk mencapai kedamaian di dalam masyarakat. Setiap warga masyarakat atau kelompok sedikit banyaknya mempunyai kesadaran hukum. Persoalan yang timbul adalah taraf kepatuhan hukum, yaitu kepatuhan hukum yang tinggi, sedang, atau kurang. Adanya derajat kepatuhan hukum masyarakat terhadap hukum, merupakan salah satu indikator berfungsinya hukum yang bersangkutan.

\section{Faktor Kebudayaan}

Kebudayaan pada dasarnya mencakup nilai-nilai yang mendasari hukum yang berlaku, nilai-nilai mana yang merupakan konsepsikonsepsi yang abstrak mengenai apa yang dianggap baik (sehingga dituruti) dan apa yang dianggap buruk (sehinga dihindari). Maka, kebudayaan Indonesia merupakan dasar atau mendasari hukum adat yang berlaku. Hukum perundang-undangan tersebut harus dapat mencerminkan nilai-nilai yang menjadi dasar dari hukum adat, agar hukum perundang-undangan tersebut dapat berlaku secara aktif. $^{13}$

Dari lima faktor penegakan hukum tersebut faktor penegakan hukumnya sendiri merupakan titik sentralnya. Hal ini disebabkan oleh baik undang-undangnya disusun oleh penegak hukum, penerapannya pun dilaksanakan oleh penegak hukum dan penegakan hukumnya sendiri juga merupakan panutan oleh masyarakat luas. ${ }^{14}$

\section{b. Teori pemidanaan}

Pemidanaan bisa diartikan sebagai tahap penetapan sanksi dan juga tahap pemberian sanksi dalam hukum pidana. Kata "pidana" pada umumnya diartikan sebagai hukum, sedangkan "pemidanaan" diartikan sebagai penghukuman. Doktrin membedakan hukum pidana materil dan hukum pidana formil.

Hukum pidana materil terdiri atas tindak pidana yang disebut berturut-turut, peraturan umum yang dapat diterapkan terhadap perbuatan itu, dan pidana yang diancamkan terhadap perbuatan itu. Hukum pidana formil mengatur cara bagaimana acara pidana seharusnya dilakukan dan menentukan tata tertib yang harus diperhatikan pada kesempatan itu. berikut: ${ }^{15}$

Tirtamidjaja menjelaskan hukum pidana meteril dan hukum pidana formil sebagai

${ }^{12}$ Ibid. hlm. 37

${ }^{13}$ Iffa Rohmahlm. 2016. Penegakkan Hukum. http://pustakakaryaifa.blogspot.com. Diakses : Pukul 12.00 WIB, Tanggal 2 Januari 2019

${ }^{14}$ Soerjono Soekanto, Op.Cit. hlm. 53

${ }^{15} \mathrm{Ibid}$, hlm. 2 
1) Hukum pidana materil adalah kumpulan aturan hukum yang menentukan pelanggaran pidana, menetapkan syarat-syarat bagi pelanggar pidana untuk dapat dihukum, menunjukkan orang dapat dihukum dan dapat menetapkan hukuman ataas pelanggaran pidana.

2) Hukum pidana formil adalah kumpulan aturan hukum yang mengatur cara mempertahankan hukum pidana materil terhadap pelanggaran yang dilakukan orangorang tertentu, atau dengan kata lain mengatur cara bagaimana hukum pidana materil diwujudkan sehingga memperoleh keputusan hakim serta mengatur cara melaksanakan putusan hakim.

Tujuan pemidanaan menurut Wirjono Prodjodikoro, yaitu: ${ }^{16}$

1. Untuk menakut-nakuti orang jangan sampai melakukan kejahatan baik secara menakut-nakuti orang banyak (generals preventif) maupun menakut-nakuti orang tertentu yang sudah melakukan kejahatan agar dikemudian hari tidak melakukan kejahatan lagi (speciale preventif), atau

2. Untuk mendidik atau memperbaiki orang-orang yang melakukan kejahatan agar menjadi orang-orang yang baik tabiatnya sehingga bermanfaat bagi masyarakat.

Pidana merupakan suatu nestapa tetapi tidak dimaksudkan untuk menderitakan dan merendahkan martabat manusia. P.A.F. Lamintang menyatakan, ${ }^{17}$ Pada dasarnya terdapat tiga pokok pemikiran tentang tujuan yang ingin dicapai dengan suatu pemidanaan, yaitu :

1) Untuk memperbaiki pribadi dari penjahat itu sendiri,

2) Untuk membuat orang menjadi jera dalam melakukan kejahatan- kejahatan, dan

3) Untuk membuat penjahat-penjahat tertentu menjadi tidak mampu untuk melakukan kejahatan-kejahatan yang lain, yakni penjahat yang dengan cara-cara yang lain sudah tidak dapat diperbaiki lagi.

Pendapat di atas dapat disimpulkan bahwa hukum pidana materil berisi larangan atau perintah jika tidak terpenuhi diancam sanksi, sedangkan hukum pidana formil adalah aturan hukum yang mengatur cara menjalankan dan melaksanakan hukum pidana materil. Pemidanaan sebagai suatu tindakan terhadap seorang penjahat, dapat dibenarkan secara normal bukan terutama karena pemidanaan itu mengandung konsekuensi-konsekuensi positif bagi si terpidana, korban juga orang lain dalam masyarakat.

\section{Hasil Penelitian Dan Pembahasan}

\section{A. Pengaturan Pelaksanaan Eksekusi Hukuman Cambuk Berdasarkan Qanun Aceh Nomor 7 tahun 2013}

Pelaksanaan Syariat Islam bidang Jinayat yang telah diatur dalam Qanun Aceh tentu saja merupakan pertanda bahwa pelaksanaan pembangunan hukum berjalan di Indonesia,

\footnotetext{
${ }^{16}$ Wirjono Prodjodikoro, Hukum Acara Pidana di Indonesia, Bandung; Sumur Bandung, 1981, hlm. 16

${ }^{17}$ P.A.F. Lamintang, Dasar-Dasar Hukum Pidana Indonesia, Bandung ; CV. Sinar Baru, 2011, hlm. 23.
} 
ini disebabkan telah terjadinya transformasi nilai-nilai syariat dalam kehidupan sehari-hari masyarakat Aceh. Meskipun pelaksanaan jinayat di Aceh masih menimbulkan masalah dan kontra karena ada yang menilai akan terjadi dualisme hukum di Indonesia.

Kegiatan penerapan hukuman cambuk bagi pelaku tidak pidana yang telah diterapkan di Aceh saat ini banyak menimbulkan pro dan kontra di berbagai kalangan. Sebagian besar masyarakat Aceh setuju dengan penerapan hukuman cambuk ini karena untuk memberi pelajaran dan efek jera kepada pelanggar syari'at Islam, dan memberi rasa takut kepada orang lain agar tidak melakukan tindak pidana yang sama. Hukuman cambuk di jatuhkan untuk memerangi faktor psikologis yang mendorong keinginan untuk melakukan kesenangan yang bertentangan dengan syari' at Islam.

Dengan ada nya hukuman cambuk tersebut, pelaku di harapkan dapat melupakan perbuatannya. ${ }^{18}$ Sementara berbagai kalangan yang lain menyatakan bahwa hukuman cambuk di Aceh melanggar HAM dan tidak manusiawi, dikatakan sebagai bentuk pembinatangan manusia, karena biasanya hanya binatang saja yang dicambuk.

Pemberlakuan syari'at Islam di Aceh pada saat ini adalah Undang-Undang No. 11 Tahun 2006 tentang Pemerintahan Aceh, yang mashur dikenal dengan UUPA. Turunan lebih lanjut dari UUPA diatur dalam Qanun Aceh, termasuk berbagai ketentuan syari'at Islam. Dengan demikian, Qanun merupakan peraturan pelaksana undang-undang.

Terkait dengan Qanun hukum jinayah, Pemerintah Aceh telah mengeluarkannya dalam dua tahapan. Pertama, pada tahun 2003 dikeluarkan tiga buah Qanun, yaitu No. 12 Tahun 2003 tentang Pelarangan Khamar, No. 13 Tahun 2003 tentang Maisir (perjudian), dan No. 14 Tahun 2003 tentang Khalwat.

Kemudian, ketiga Qanun tersebut digabung dalam satu Qanun dengan tambahan tujuh materi jarimah (tindak pidana) lainnya. Qanun tersebut adalah Qanun No. 6 Tahun 2014. Jadi, perbuatan jarimah dalam Qanun No. 6 Tahun 2014 berjumlah 10 bentuk.

Secara lengkap, jarimah dalam Pasal 3 ayat (2) Qanun No 6 Tahun 2014 meliputi:

a. Khamar (minuman memabukkan);

b. Maisir (perjudian);

c. Khalwat (berdua-duaan di tempat tertutup atau tersembunyi antara laki-laki dan perempuan yang bukan mahram dan ikatan perkawinan yang mengarah pada perbuatan zina);

d. Ikhtilath (perbuatan bermesraan seperti bercumbu,bersentuh-sentuhan, berpelukan dan berciuman antara laki-laki dan perempuan yang bukan suami istri dengan kerelaan kedua belah pihak, baik pada tempat tertutup atau terbuka);

e. Zina;

f. Pelecehan seksual;

${ }^{18}$ Eldin H. Zainal, Perbandingan Mazhab Tentang Hukum Pidana Islam lMuqarranah Al-Mazahib Fi AlJinayah, Medan: Fakultas Syari'ah IAIN-SU, 2010, hlm. 54 


\section{g. Pemerkosaan;}

h. Qadzaf (menuduh seseorang melakukan zina tanpa bukti);

i. Liwath (perbuatan homo seksual); dan

j. Musahaqah (perbuatan lesbian).

Terkait dengan pelaksanaan hukuman cambuk terhadap pelaku jinayah diatur dengan Qanun Aceh Nomor 7 Tahun 2013 tentang hukum acara Jinayah. Tentunya qanun tersebut tidak dapat berdiri sendiri karena wajib harus didahului dengan qanun nomor 6 tahun 2014 tentang hukum jinayah.

Penjelasan diatas sesuai dengan Pasal 247 Qanun Aceh Nomor 7 Tahun 2013 tentang Hukum Acara jinayah yang berbunyi :

(1) Pelaksanaan 'Uqubat adalah kewenangan dan tanggung jawabJaksa Penuntut Umum.

(2) Pelaksanaan 'Uqubat sebagaimana dimaksud pada ayat (1) segeradilaksanakan setelah adanya putusan Mahkamah yang mempunyaikekuatan hukum tetap.

(3) Dalam melaksanakan tugas Jaksa Penuntut Umum dapat memintabantuan kepada instansi/lembaga terkait.

Kemudian dalam Pasal 252 dijelaskan juga bahwa :

(1) Pelaksanaan 'Uqubat cambuk dilakukan oleh jaksa denganmenyiapkan tempat pencambukan, menentukan waktu dan menunjukpencambuk.

(2) Untuk penentuan tempat dan waktu pencambukan sebagaimanadimaksud pada ayat (1) Jaksa berkoordinasi dengan KetuaMahkamah Syar'iyah, Kepala Dinas Kesehatan dan Instansi yangmembawahi Wilayatul Hisbah Kabupaten/kota setempat.

Sedangkan dalam Pasal 253 disebutkan juga bahwa :

(1) Atas permintaan jaksa, instansi yang membawahi Wilayatul Hisbahkabupaten/kota setempat mempersiapkan pencambuk.

(2) Kepala Instansi yang membawahi Wilayatul Hisbah sebagaimanadimaksud pada ayat (1) memberitahukan kesiapan petugaspencambuk kepada jaksa sebelum waktu pencambukan.

Dalam hukum pidana Jinayah maupun hukum acara jinayah sama sekali tidak ada di dalam Hukum Pidana nasional, baik umum maupun khusus. Kalau ada perbuatan pidana yang tidak sama rumusannya di dalam hukum pidana nasional yang dilakukan oleh non-muslim, maka dikenakan Qanun Aceh. Banyak orang lupa, bahwa ancaman pidana yang ada di dalam Qanun Jinayah itu bukan hanya cambuk, melainkan ada penjara dan denda. Qanun Jinayat tidak identik dengan pidana cambuk. Hakim bebas memilih pidana lain selain cambuk.

Dari uraian diatas dapat disimpulkan bahwa Pengaturan Pelaksanaan Eksekusi Hukuman Cambuk Berdasarkan Qanun Aceh Nomor 7 tahun 2013 tentang hukum acara 
jinayah diatur dalam Pasal 247, 252 dan 252 yang dimana jaksa penuntut umum memiliki kewenangan untuk melaksanakan pencambukan dengan berkoordinasi dengan kepalainstansi yang membawahi wilayatul Hisbah dalam proses pelaksanaan eksekusi.

\section{B. Efektifitas Pelaksanaan Eksekusi Hukuman Cambuk Terhadap Pelaku Jinayat Di Kabupaten Aceh Tamiang Dalam Perspektif Qanun Hukum Acara Jinayah}

Sebelum kita berbicara mengenai efektif atau tidak efektifnya penerapan sanksi pidana cambuk dalam menekan tindak pelanggaran Qanun di bidang Syariat Islam terkait dengan tindak pidana perjudian, ada baiknya kita mengetahui apakah yang ingin dicapai dengan pelaksanaan Syariat Islam secara kaffah di Propinsi Nanggroe Aceh Darussalam umumnya dan di Kabupaten Aceh Tamiang khususnya.

Sekurang kurangnya ada empat jawaban untuk pertanyaan ini:

a. tujuan yang ingin dicapai dengan alasan agama (alasan teologis) bahwa pelaksanaan Syariat merupakan perintah Agama, untuk dapat menjadi muslim.

b. tujuan dengan alasan psikologis, bahwa masyarakat akan merasa lebih aman dan tentram karena apa yang berlaku disekitar mereka, kegiatan yang mereka jalani dalam pendidikan, dalam kehidupan sehari-hari dan seterusnya sesuai dan sejalan dengan kesadaran dan kata hati mereka sendiri.

c. tujuan dengan alasan hukum, masyarakat akan hidup dalam tata aturan yang lebih sesuai dengan kesadaran hukum, rasa keadilan dan nilai-nilai yang tumbuh dan berkembang ditengah masyarakat.

d. tujuan dengan alasan ekonomi dan kesejahteraan sosial, bahwa nilai tambah pada kegiatan ekonomi, serta kesetia kawanan sosial dalam bentuk tolong menolong baik untuk kegiatan ekonomi atau untuk kegiatan sosial akan lebih mudah terbentuk dan lebih solid. Anggota masyarakat di harapkan akan lebih rajin bekerja, akan lebih hemat dan juga lebih bertanggung jawab.

Pelaksanaan hukuman cambuk merupakan implementasi disahkannya sistem pemerintahan Syariat Islam di provinsi Aceh. Hukuman cambuk dijatuhkan bagi pelanggaran tertentu yang diatur dalam Qanun Nomor 12 tentang Minuman Khamar (minuman keras) dan sejenisnya, Qanun Nomor 13 tentang Maisir (perjudian), dan Qanun Nomor 14 tentang Khalwat (mesum) saat ini Qanun itu semua telah di rangkap dalam Qanun yang baru yaitu Qanun Jinayat Nomor 6 Tahun 2014.

Pemerintah Kabupaten Aceh Tamiang menggalakkan hukuman cambuk adalah bertujuan untuk membuat jera para pelaku pelanggar syari' at islam. Jera yang dimaksud disini bukanlah karena telah mendapat penyiksaan badan. Melainkan karena si terhukum dan keluarga terhukum tersebut telah merasa sangat malu. Rasa malu yang di dapat ini lah yang selanjutnya diharapkan si terhukum tersebut benar-benar bertaubat, dan berjanji kepada Allah untuk tidak melakukan perbuatan serupa.

Namun setelah putusan mahkamah syar'iyah kuala simpang terkait dengan pelaksanaan hukuman cambuk disamping melibatkan beberapa institusi dan juga harus melalui prosedur yang dimana diantaranya adalah: 
1. Jaksa sebagai pelaksana eksekusi uqubat cambuk

2. Jaksa menyiapkan tempat dan waktu pencambukan dengan terlebih dahulu berkoordinasi dengan Ketua Mahkamah Syariah, kepala dinas kesehatan dan instansi yang membahwahi wilayatul hisbah atau dinas syariat Islam kabupaten/kota setempat

3. Atas permintaan jaksa, instansi yang membawahi wilayatul hisbah dan dinas syariat Islam kabupaten/kota setempat mempesiapkan pecambuk dan memberitahukan kesiapan petugas pecambuk tersebut kepada jaksa sebelum waktu pencambukan

4. Jaksa menunjuk pecambuk (eksekutor), yaitu petugas wilayatul hisbah yang ditugaskan untuk melakukan pencambukan atas terhukum. ${ }^{19}$

5. Atas permintaan jaksa, kepala dinas kesehatan kabupaten/kota menyiapkan dokter yang akan memeriksa kesehatan terhukum sebelum dan sesudah pelaksanaan pencambukan dan mengirimkan nama dokter yang ditunjuk sebelum waktu pemeriksaaan tiba

6. Hasil pemeriksanaan dokter harus dituangkan dalam bentuk surat keterangan dan diserahkan sebelum pelaksanaan uqubat cambuk kepada jaksa

7. Jaksa harus mematuhi hasil pemeriksanaan dokter yang ditunjuk

8. Jaksa wajib memberitahukan waktu dan tempat pemeriksanaan kesehatan kepada hakim pengawas, dokter yang ditunjuk, dan petugas pecambuk sebelum waktu pemeriksaaan kesehatan

9. Jaksa wajib memberitahukan waktu dan tempat pelaksanaan pencvambukan kepada hakim pengawas, dokter yang ditunjuk, dan petugas cambuk sebelum waktu pelaksanaan pencambukan

10. Hakim pengawas, dokter yang ditunjuk, dan petugas pencambukan harus hadir ditempat pelaksanaan pencambukan

11.Pencambukan tidak dapat dilaskanakan apabila hakim pengawas, dokter yang ditunjuk, petugas pencambuk atau jaksa tidak hasdir di tempat dan pada waktu pelaksanaan pencambukan

12.Jaksa menghadirkan terhukum yang ditahan ke tempat pemeriksa kesehatan dan tempat pelaksanaan pencambukan dengan terlebih dahulu memberiahukan kepada keluarga atau Keucik atau nama lain di tempat tinggalnya secara tertulis, paling lambat 1 (satu) hari sebelum tanggal pemeriksanaan dan tanggal pencambukan.

13.Dalam hal terhukum (keluarga terhukum) berdomisili di luar daerah hukum jaksa yang bersangkutan, atau terhukum dijatuhi uqubat tidak lebih dari 4 (empat) kali, maka pemberitahuan kepada keluarga atau Keucik tidak perlu dilakukan

14.Dalam hal terhukum tidak ditahan, jaksa penuntut umum melakukan pemanggilan untuk menjalani proses pelaksanaan uqubat secara sah disampakan dengan surat panggilan kepada terhukum di alamat tempat tinggalnya, atau apabila tempat tinggalnya tidak dketahui, disampaikan ditempat kediamannya terkahir, surat panggilan disampaikan melalui Keucik atau nama lain dan/atau perangkat gampong tempat tinggal terhukum atau tempat kediaman terakhir terhukum selambatlambatnya tiga hari sebelum hari pencambukan dengan tanda penerimaan. Dan apabila sudah dilakukan pemanggilan satu sampai dua kali, namun tetap tidak hadir maka dilakukan pemanggilan secara paksa dengan terlebih dahulu mendapatkan penetapan hakim

15.Pemanggilan secara sah sebagaimana dikemukakan di atas dapat didukung dengan sarana komunikasi teknologi lainnya

\footnotetext{
${ }^{19}$ Pasal 1 ayat (11) Pergub No. 10 Tahun 2005 tentang Petunjuk Teknis Pelaksanaan Uqubat Cambuk
} 
16. Sebelum pelaksanaan pencambukan kepada terhukum dapat diberikan bimbingan rohani singkat oleh seorang ulama atas permintaan jaksa atau terhukum

17. Sebelum pencambukan, jaksa hanya membacakan identitas terhukum, jarimah yang dilakukan dan uqubat yang dijatuhkan mahkamah yang sudah mempunyai kekuatan hukum tetap.

18.Uqubat cambuk dilaksanakan di suatu tempat terbuka dan dapat dilihat oleh orang yang hadir

19.Pelaksanaan uqubat cambuk tidak boleh dihadiri oleh anak-anak di bawah umur 18 (delapan belas) tahun

20.Pelaksanaan uqubat cambuk dilaksanakan di atas alas (bidang) berukuran minimal 3 x 3 meter

21.Jarak antara tempat berdiri terhukum dan masyarakat yang menyaksikan paling dekat 12 (dua belas) meter

22.Jaksa, hakim pengawas, dokter yang ditunjuk, dan petugas pecambuk berdiri di atas atau sekitar alas selama pencambukan berlangsung

23.Pecambuk hadir ditempat pencambukan dengan menggunakan cambuk berupa alat pemukul yang dibuat dari rotan berdiameter 0,75 sampai dengan 1 (satu) sentimeter, panjang satu meter, tidak mempunyai ujung ganda dan pada pangkalnya ada tempat pegangan yang disediakan oleh jaksa dengan memakai penutup wajah dari kain

24.Pencambukan dilakukan pada punggung (bahu sampai pinggul) terhukum

25.Jarak anatara terhukum dan pecambuk anatara 0,70 meter sampai dengan 1 (satu) meter dengan posisi pecambuk berdiri di sebelah kiri terhukum

26.Pecambuk dapat membuat kuda-kuda dengan jarak antara kaki kiri dan kanan paling jauh $50 \mathrm{~cm}$

27.Pecambuk dapat menekuk tangan serta mengayun cambuk ke samping atau ke belakang dan posisi ujung tangannya tidak lebih tinggi dari bahu

28. Apabila pecambuk tidak sanggup menyelesaikan pekerjaaannya, maka pecambukan akan dilanjutkan oleh pencambuk lainnnya

29.Pecambuk melakukan pencambukan atas perintah dan aba-aba jaksa

30.Cambukan yang sudah dilaksanakan pencambuk tidak dapat dibatalkan

31.Jaksa akan menegur, memperbaiki posisi dan/atau menukar pencambuk apabila salah satu ketentuan pencambukan tidak terpenuhi

32.Pada saaat pencambukan, terhukum diharuskan menggunakan baju tipis menutup aurat yang telah disedakan oleh jaksa, dan berada dalam posisi bebas dan berdiri tanpa penyangga bagi laki-laki dan dalam posisi duduk bagi terhukum perempuan, terkecuali atas permintaan terhukum atau dokter, terhukum dapat dicambuk sambil duduk besimpuh atau berdiri dengan penyangga, namun harus dalam keadaan bebas.

33.Pencambukan akan dihentikan sementara, apabila diperintahkan oleh dokter yang bertugas berdasarkan pertimbangan medis, atau terhukum melarikan diri dari tempat pencambukan sebelum uqubat cambuk selesai dilaksanakan

34. Setelah pelaksanaan pencambukan, jaksa membuat berita acara pelaksanaan pencambukan dan menandatanganinya bersama-sama dengan hakim pengawas dan dokter sebagai saksi

35.Jaksa menyerahkan satu lembar salinan berita acara kepada terhukum atau keluarganya sebagi bukti bahwa terhukum telah menjalani seluruh atau sebagian hukuman

36.Jaksa mengirimkan tembusan berita acara pelaksanaan putusan mahkamah yang ditandatangani olehnya, terhukum dan/atau lembaga pemasyarakatan kepada mahkamah yang memutus perkara pada tingkat pertama dan panitra mencatatnya dalam register pengawasan dan pengamatan. 
37.Pengawalan dan pengamanan terhukum dan pelaksanaan eksekusi dilaksanakan oleh kepolisian setempat

Pelaksanaan hukuman atau eksekusi biasanya dilakukan di halaman Masjid Kabupaten Aceh Tamiang seusai sholat Jum`at. pelaksanaan eksekusi ini dihadiri oleh sejumlah pejabat, media massa dan di saksikan beramai ramai oleh masyarakat Kuala simpang. Adapun Persiapan yang dilakukan, yaitu disediakan Panggung berukuran 3 x 3 meter persegi di halaman Masjid. Diatas panggung, dibuat garis lingkar berdiameter 1 meter, disinilah tempat para terhukum dieksekusi.

Namun pada sat ini pelaksanaan hukuman cambuk tidak dilakukan pada setiap hari jum'at, sehingga para pelaku jinayah yang telah memiliki kekuatan hukum tetap harus mendekam dulu di dalam penjara. Hal tersebut mengakibatkan penerapan 2 sanksi terhadap pelaku yang 1) pelaku dicambuk, 2) dipenjara sebelum proses pencambukan.

Rasa malu yang didapatkan oleh para pelaku sudah cukup besar pengaruhnya, sehingga para pelaku dapat berubah menjadi lebih baik. Pelaksanaan hukuman seperti ini menekan keinginan kotor dan moral yang buruk masyarakat, serta secara alamiah mempunyai pengaruh pada jiwa juga ketaatan. Akan tetapi, dan mungkin juga sangat mengejutkan, kerasnya hukuman -hukuman dalam hukum pidana Islam sangat jarang dijatuhkan karena ketatnya hukuman pembuktian yang melindungi hak-hak manusia.

Namun yang menjadi ketimpang di lapangan adalah setelah adanya putusan mahkamah syar'iyah, para pelaku jinayah tidak langsung di cambuk, tapi harus menunggu jadwal pencambukan.

Sebagaimana pernyataan dari M. Yani yang menjelaskan bahwa:

"Sebagai salah satu pelaku jinayah yang pernah diputuskan oleh pengadilan, saya begitu sangat mendukung pelaksanaan hukuman cambuk yang dilakukan oleh wilayatul hisbah, sehingga dapat membuat saya berubah menjadi lebih baik. Rasa malu yang saya dapatkan begitu besar dan sehingga berjumpa kerabat maupun sahabat tidak berani untuk saya lakukan. Namun menunggu jadwal cambuk itulah yang sangat lama hingga berbulan-bulan baru dilakukan eksekusi oleh jaksa penuntut umum,"20

Hal tersebut diatas seharusnya tidak boleh terjadi, karena di dalam Pasal 29 ayat 2 disebutkan bahwa :

"Masa Penahanan untuk pelaku jarimah yang ancaman uqubatnya penjaranya paling lama 12 (dua belas) bulan sebagaimana dimaksud pada ayat (1) berlaku ketentuan sebagai berikut" :

a. Penyidikan, paling lama 15 (lima belas) hari;

b. Penuntutan, paling lama 5 (lima) hari ;

c. Pemeriksaan pada Mahkamah Syar`iyah Kabupaten/Kota, paling lama 15 (lima belas) hari;

\footnotetext{
${ }^{20}$ Hasil wawancara dengan M. Yani, Eks Pelaku Jinayah, Kabupaten Aceh Tamiang, tanggal 14 Februari 2019
} 
d. Pemeriksaan banding pada Mahkamah Syar'iyah Aceh, paling lama 20 (dua puluh) hari; dan

e. Pelaksanaan uqubat, paling lama 5 (lima) hari.

Pada Pasal 29 ayat 2 huruf e jelas disebutkan bahwa pelaksanaan uqubat paling lama 5 (lima) hari sejak diputuskan oleh Mahkamah Syar`iyah Kabupaten/Kota. Namun Pelaksanaan yang terjadi adalah pelaksanaan uqubat bagi pelaku jinayah tidak seperti yang telah diatur dalam pasal tersebut.

Dari beberapa fakta dilapangan setelah putusan mahkamah syar'iyah terhadap pelaku jinayah tidak langsung dilakukan eksekusi oleh jaksa, karena jaksa juga menunggu kesiapan dari instansi terkait.

Dari uraian diatas dapat disimpulkan bahwa efektifitas pelaksanaan eksekusi hukuman cambuk terhadap pelaku jinayat di Kabupaten Aceh Tamiang dalam perspektif qanun hukum acara jinayah belum berjalan secara optimal, dikarenakan setelah inkrahnya putusan mahkamah syar'iyah terhadap pelaku jinayah tidak langsung dilakukannya pencambukan sehingga para pelaku harus mendekam terdahulu kedalam penjara.

\section{Hambatan Dan Upaya Dalam Pelaksanaan Eksekusi Hukuman Cambuk Terhadap Pelaku Jinayat Di Kabupaten Aceh Tamiang}

Ada beberapa hambatan yang menjadi penyebab pelaksanaan 'uqubah cambuk di Kabupaten Aceh Tamiang yang tidak sesuai dengan mekanisme pelaksanaan 'uqubah cambuk di dalam Hukum Acara Jinayat, diantaranya sebagai berikut:

1. Aparatur hukum tidak patuh hukum

Kepatuhan hukum adalah ketaatan terhadap hukum, patuh terhadap hukum yang berlaku bukan hanya kewajiban masyarakat, tetapi juga kewajiban aparatur hukum. Aturan yang sudah dibuat dan diatur sedemikian rupa gunanya untuk menciptakan keadilan dan untuk kemaslahatan manusia seluruhnya. Namun dalam praktiknya sering sekali terjadi hal-hal yang bertentangan dengan aturan yang berlaku.

Banyak ketentuan-ketentuan yang diatur dalam Hukum Acara Jinayat yang dilanggar oleh aparatur hukum. Seperti hadirnya anak-anak di bawah umur 18 (delapan belas) tahun menyaksikan proses pencambukan secara langsung. Walaupun demikian namun aparatur hukum tetap melanjutkan proses eksekusi jika terjadi hal tersebut dan ini bertentangan dengan Pasal 262 ayat (2) Qanun Hukum Acara Jinayat. Dimana pengawasan pelaksanaan 'uqubah cambuk di lokasi pencambukan diabaikan oleh aparatur hukum. Ketidakpatuhan hukum oleh aparatur hukum menjadi faktor penghambat pengawasan pelaksanaan 'uqubah cambuk di Kabupaten Aceh Tamiang.

2. Tidak ada dukungan dari pemerintah setempat berupa alokasi dana maupun sumber daya lainnya untuk terlaksananya hukuman cambuk. 
Tanpa adanya sarana atau fasilitas tertentu, maka tidak mungkin penegakan hukum akan berlangsung dengan lancar. Sarana atau fasilitas hukum tersebut antara lain, mencakup tenaga manusia yang berpendidikan dan terampil, organisasi yang baik, peralatan yang memadai, keuangan yang cukup dan seterusnya.

Berbagai problem dalam sarana dan prasarana ini adalah :

a) Kurangnya Sumber Daya Manusia

Sumber Daya Manusia yang terbatas sehingga mengakibatkan permasalahan yang akan mengganggu kelancaran penegakan hukum tersebut.

b) Rusaknya penegak / Sumber Daya Manusia

Akibat terperosoknya Sumber Daya Manusia mengakibatkan banyak penyimpangan hukum dan memudahkan untuk dilakukan.

c) Lemahnya pembangunan sehingga kurangnya sarana dan prasarana serta perlengkapan dalam menjalankan penegakan hukum.

d) Minimnya dana yang dialokasikan.

Dengan demikian dapat disimpulkan bahwa sarana dan fasilitas mempunyai peranan yang sangat penting di dalam penegakan hukum. Tanpa adanya sarana atau fasilitas tersebut tidak akan mungkin penegak hukum menyelesaikan peranan yang aktual.

Sama halnya dengan pelaksanaan eksekusi hukuman cambuk, yang seharusnya ketika setelah ingkrah dari mahkamha syar'iyah maka eksekusi langsung dapat dilakukan. Namun yang terjadi adalah penundaan yang begitu lama sehingga pelaku terpidana harus mendekam terlebih dahulu di dalam penjara.

3. Masa daluwarsa untuk pelaksanaan eksekusi cambuk adalah 3 bulan setelah putusan dijatuhkan, apabila tidak dijalankan maka terhukum dilepaskan

Eksekusi terhadap Penghukuman terhadap pelaku jinayah memiliki batas waktu yang telah ditentukan di dalam Qanun Aceh nomor 7 tahun 2013 tentang hukum acara jinayah.

Salah satu Pasal 270 yang menjelaskan hal tersebut adalah :

1) Apabila tiga bulan setelah putusan Mahkamah yang telah mempunyai kekuatan hukum tetap diserahkan kepada jaksa, hukuman belum dilaksanakan tanpa alasan yang sah, maka Jaksa dianggap telah melalaikan tugas.

2) Jaksa sebagaimana yang dimaksud pada hal diatas dikenakan hukuman sesuai dengan Peraturan Perundang-undangan.

Kemudian pada Pasal 271 disebutkan :

1) Pelaksanaan `Uqubat tidak menjadi kadaluwarsa atas terhukum yang tidak menjalani 'uqubat sebagaimana dimaksud dalam Pasal 258, atau tidak menyelesaikan `uqubat sebagaimana dimaksud dalam Pasal 259 ayat (2) dan Pasal 265.

2) Apabila 'Uqubat tidak dilaksanakan atau tidak selesaidilaksanakan sebagaimana dimaksud pada ayat (1) danterhukum dijatuhi 'Uqubat baru maka semua 'Uqubat dilaksanakan sekaligus. 
Penafsiran pasal diatas kita simpulkan bahwa apabila tersangka ditahan oleh jaksa pada saat pemeriksaan, maka setelah putusan yang telah berkekuatan hukum tetap apabila belum dilakukan eksekusi pencambukan terhadap terpidana maka tindak pidana tersebut menjadi kadaluwarsa.

4. tidak ada hukuman pengganti atasnya.

Pada qanun jinayah terdapat 3 sanksi yang diterapkan yaitu penjara, denda dan cambuk. Namun ketiga sanksi tersebut hanya hukuman cambuk yang dapat diterapkan kepada pelaku apabila terdapat sanksi lainnya. Pasal 73 ayat (3) Qanun Aceh Nomor 6 tahun 2014 tentang hukum jinayah dijelaskan bahwa :

"Dalam hal 'Uqubat dalam qanun lain sebagaimana dimaksud pada ayat (1) bersifat alternatif antara penjara, denda atau cambuk, yang dijadikan pegangan adalah 'Uqubat cambuk".

Adapun untuk menanggulangi pelaksanaan eksekusi hukuman cambuk terhadap pelaku jinayat di Kabupaten Aceh Tamiang dapat dilakukan dengan beberapa upaya yang dimana diantara :

1. Perlunya anggaran yang memadai bagi pelaksanaan cambuk

Pelaku tindak pidana jinayah tentunya sangat banyak, sehingga perlu adanya anggaran yang memadai untuk pelaksanaan hukuman cambuk tersebut. Oleh karena itu perlu adanya anggaran yang memadai demi terlaksananya hukuman cambuk bagi pelaku jinayah secara optimal.

2. Profesionalitas penegak hukum dalam pelaksanaan cambuk bagi pelaku jinayah

Profesionalitas sangatlah dibutuhkan bagi setiap pelayan publik. Hal ini tidak terlepas dan berlaku juga bgi aparat penegak hukum, baik jaksa, polisi wilayatul hisbah maupun dinas syariat islam. Sehingga dengan adanya profesionalitas dari lembagalembaga tersebut maka efektifitas pelaksanaan hukuman cambuk dapat berjalan secara optimal.

3. Adanya hukuman pengganti selain cambuk.

Setiap kasus yang terjadi dalam pelaksanaan cambuk terhadap pelaku jinayah yang tidak dilaksanaka oleh penegak hukum dikarenakan lemahnya di sisi anggaran, maka sudah seyogianya hakim selaku pemutus akhir dari pada hukuman pelaku untuk juga dapat menerapkan hukuman pengganti selain cambuk seperti penerapan denda maupun pemenjaraan.

Dari uraian diatas dapat disimpulkan bahwa hambatan dalam pelaksanaan eksekusi hukuman cambuk terhadap pelaku jinayat di Kabupaten Aceh Tamiang adalah Aparatur hukum tidak patuh hukum, Tidak ada dukungan dari pemerintah setempat berupa alokasi dana maupun sumber daya lainnya untuk terlaksananya hukuman cambuk. tidak ada hukuman pengganti atasnya. Sedangkan upaya yang dapat dilakukan adalah perlunya anggaran yang memadai bagi pelaksanaan cambuk dan Profesionalitas penegak hukum 
dalam pelaksanaan cambuk bagi pelaku jinayah serta adanya hukuman pengganti selain cambuk.

\section{Penutup}

\section{A. Kesimpulan}

Pengaturan Pelaksanaan Eksekusi Hukuman Cambuk Berdasarkan Qanun Aceh Nomor 7 tahun 2013 tentang hukum acara jinayah diatur dalam Pasal 247, 252 dan 252 yang dimana jaksa penuntut umum memiliki kewenangan untuk melaksanakan pencambukan dengan berkoordinasi dengan kepala instansi yang membawahi wilayatul Hisbah dalam proses pelaksanaan eksekusi.

Efektifitas pelaksanaan eksekusi hukuman cambuk terhadap pelaku jinayat di Kabupaten Aceh Tamiang dalam perspektif qanun hukum acara jinayah belum berjalan secara optimal, dikarenakan setelah inkrahnya putusan mahkamah syar'iyah terhadap pelaku jinayah tidak langsung dilakukannya pencambukan sehingga para pelaku harus mendekam terdahulu kedalam penjara.

Hambatan dalam pelaksanaan eksekusi hukuman cambuk terhadap pelaku jinayat di Kabupaten Aceh Tamiang adalah Aparatur hukum tidak patuh hukum, Tidak ada dukungan dari pemerintah setempat berupa alokasi dana maupun sumber daya lainnya untuk terlaksananya hukuman cambuk. tidak ada hukuman pengganti atasnya. Sedangkan upaya yang dapat dilakukan adalah perlunya anggaran yang memadai bagi pelaksanaan cambuk dan Profesionalitas penegak hukum dalam pelaksanaan cambuk bagi pelaku jinayah serta adanya hukuman pengganti selain cambuk.

\section{B. Saran}

Disarankan kepada Pemerintah Kabupaten Aceh Tamiang agar memberikan dukungan anggaran/alokasi dana dalam penegakan syariat Islam.

Disarankan kepada Jaksa untuk melakukan evaluasi terhadap putusan-putusan yang telah inkracht agar dapat segera dijalankan eksekusi dan dapat menjadi daluwarsa untuk pelaksanaan eksekusi cambuk apabila selama 3 bulan setelah putusan dijatuhkan tidak dilakukannya pencambukan kepada pelaku.

Disarankan kepada penegak hukum dalam menangani perkara jinayat di Kabupaten Aceh Tamiang ke depan haruslah menjadi tanggung jawab seccara kolektif sebab tanpa kemauan dan niat baik mustahil penegakan hukum jinayat dapat diwujudkan. Salah satu yang terpenting adalah pemahaman penegak hukum terhadap hak dankewajiban. 


\section{DAFTAR PUSTAKA}

\section{A. Buku-buku}

Achmad Ali. Menguak Teori Hukum (Legal Theory) dan Teori Peradilan (Judicialprudence) Termasuk Interpretasi Undang-Undang (Legisprudence). Jakarta:Penerbit Kencana, 2009.

Anonimous, Kamus Besar Bahasa Indonesia. Jakarta:Balai Pustaka, 2008.

Al Yasa` Abubakar, "Pelaksanaan Syari at Islam di Aceh: Sejarah dan Prospek", dalam Fairus M. Nur Ibrahim (ed), Syariat di Wilayah Syariat, Banda Aceh: Dinas Syariat Islam Provinsi Nanggroe Aceh Darussalam, 2002.

-----, Sekilas Syariat Islam Di Aceh, Dinas Syariat Islam Provinsi NAD, Banda Aceh, 2006.

--------, Syari'at Islam di Provinsi Nanggroe Aceh Darussalam: Paradigma, Kebijakan dan Kegiatan, Dinas Syariat Islam Aceh, Banda Aceh, 2005.

Wirjono Prodjodikoro, Hukum Acara Pidana di Indonesia, Sumur Bandung, Bandung, 1981.

P.A.F. Lamintang, Dasar-Dasar Hukum Pidana Indonesia, CV. Sinar Baru, Bandung, 2011.

Eldin H. Zainal, Perbandingan Mazhab Tentang Hukum Pidana Islam lMuqarranah AlMazahib Fi Al-Jinayah, Fakultas Syari' ah IAIN-SU, Medan, 2010.

Soerjono Soekanto. Faktor-Faktor yang Mempengaruhi Penegakan Hukum, PT. Raja Grafindo Persada, Jakarta, 2007.

Sudirman Tebba, Sosiologi Hukum Islam, UII Press, Yogyakarta, 2003.

Teungku Ahmad Zamzami, 2007, Dkk, Pemikiran ulama dayah Aceh, Jakarta: Prenada.

\section{B. Perundang-Undangan}

Undang-Undang Dasar Negara Republik Indonesia Tahun 1945

Undang-Undang Nomor 11 Tahun 2006 tentang Pemerintah Aceh (Lembaran Negara Republik Indonesia Tahun 2006 Nomor 62, Tambahan Lembaran Negara Republik Indonesia Nomor 4633)

Qanun Nomor 7 Tahun 2013 tentang Hukum Acara Jinayat (Lembaran Aceh Tahun 2013 Nomor 7, Tambahan Lembaran Aceh Nomor 51)

Qanun Nomor 6 Tahun 2014 Tentang Hukum Jinayat (Lembaran Aceh Tahun 2014 Nomor 7, Tambahan Lembaran Aceh Nomor 66) 
P-ISSN : : 2615-3416

Volume 15, Nomor 2, Juli-Desember 2020

\section{Sumber Lain}

https://id.wikipedia.org/wiki/Kabupaten_Aceh_Tamiang diakses pada tanggal 2 Januari 2019

Iffa Rohmah. 2016. Penegakkan Hukum. http://pustakakaryaifa.blogspot.com. Diakses : Pukul 12.00 WIB, Tanggal 2 Januari 2019 